\title{
Review and Analysis of the Projects Logistics of International Engineering Contracting Enterprises
}

\author{
Yingmei $\mathrm{Fu}$ * \\ International Business School \\ Yunnan University of Finance and Economics \\ Kunming, China \\ yingmei1006@163.com
}

\author{
Yong $\mathrm{Yu}$ \\ International Business School \\ Yunnan University of Finance and Economics \\ Kunming, China \\ yuyong01@vip.163.com
}

\begin{abstract}
With the economic globalization trend and China's "going out" and "The belt and Road" proposal, international engineering contracting activities are more and more frequent. However, as the contract of international engineering projects involve a wide range and occupy a huge capital, any link going wrong will lead to entire project delay or even fall into stagnation. So, analyze the logistics management at the present stage of China's overseas engineering contracting projects, find the reasons for the problems combining with practice to find out the factors influencing logistics management, and in view of the main problems, conduct depth profiling, using it as a breakthrough to put forward optimization strategy to solve the problem, which has profound significance.
\end{abstract}

Keywords-Logistics; International Engineering Projects; Optimization

\section{INTRODUCTION}

Chinese enterprises engaged in overseas engineering contracting business beginning from the development of China's foreign aid, initially mainly for helping some countries to build a number of small projects. After the reform and opening-up, Chinese enterprises began to pour into the international engineering contract market. In the late 1980s, the scale of China's foreign projects contracting and labor service cooperation business has been expanding year by year, and the operation field is also widening. In 1999, according to the situation, Chinese government clearly putted forward the strategy of "going out". This decision not only promote the domestic enterprises of various sectors to go out of the country committing to overseas market development, but also is conducive to the diversification and in-depth development of foreign projects contracting.

Now the advocate of "The Belt and Road" encourages more superior productivity to go out, which laid the policy basis for our overseas project contracting enterprises to further develop the overseas business. At present, the global economy is still in the volatility adjustment stage of slow recovery from the post crisis era. Countries are trying to stimulate economic recovery through increasing investment in infrastructure and project contract market is a breakthrough to promote the national economy out of the slump.

As for the development of Chinese project contracting industry, to promote the investment of infrastructure, and to improve infrastructure transformation and upgrading of the related countries of "The Belt and Road" is in line with the national "The Belt and Road" requirements, but also meet the demand of countries along in the aspects of energy, information, power and other infrastructure. According to the
National Bureau of statistics, During 1 9 months of 2015, China's enterprises sign 3059 copies projects in 57 countries related the "The Belt and Road", and the new contract amount is $\$ 59.1$ billion, which accounted for $42.9 \%$ of China's new contract amount of foreign contracted projects, increase by $24.9 \%$. Completed turnover is $\$ 44.02$ billion, accounting for $43.7 \%$ of the total turnover in the same period, increase by $5 \%$. It is not only the number of projects increased, but also the proportion of large and super large projects increased.

At present, China International Engineering Contractor in the African market accounted for the maximum, and the advantage is more obvious. The competition in the Asian markets with the United States, Germany and Spain is fierce. The contractors in the Middle East market are mainly facing competition from South Korea and the United States, Italy contractor. China international engineering contracting are developing Asian, African, the Middle East and other traditional markets at the same time, but also need to increase efforts to develop new markets in Latin America and the Caribbean and other emerging markets. In recent years, China's international contractors involved in the construction of the project has also changed to more and more diversified development, including transportation, housing, electricity, electronic communications industry. ENR 2014 annual list shows 62 Chinese companies listed in the world's largest contractor top 250 list, and the highest ranking of Chinese enterprises move forward one step further ranked ninth.

TABLE I. NEW CONTRACT AMOUNT AND TURNOVER OF FOREIGN CON TRACTING PROJECTS OF CHINESE ENTERPRISES

UNIT: BILLION

\begin{tabular}{|c|c|c|}
\hline Year & New contract amount & Turnover \\
\hline $\mathbf{2 0 1 0}$ & 134.40 & 92.20 \\
\hline $\mathbf{2 0 1 1}$ & 142.33 & 103.42 \\
\hline $\mathbf{2 0 1 2}$ & 156.53 & 116.60 \\
\hline $\mathbf{2 0 1 3}$ & 171.63 & 137.14 \\
\hline $\mathbf{2 0 1 4}$ & 191.71 & 142.10 \\
\hline $\mathbf{2 0 1 5}$ & 210.07 & 154.07 \\
\hline
\end{tabular}

In the past six years, the new contract amount and turnover of foreign contracting projects in our country is shown in the following table:

Because the contract of international engineering projects involve a wide range and occupy a huge capital. Design, supply, logistics, installation, commissioning, and operation 
connect and interlock each other closely, and any link going wrong will lead to entire project delay or even fall into stagnation. In this supply chain, logistics is a very important link, which connects factories, suppliers, subcontractors, the project site and the owners to a line. From the factory to the port of shipment, and then to the port of destination and the construction site, the international logistics realized the foreign transfer of goods and materials and the handover of the right of the goods. It can be said that the international project logistics is the foundation of a smooth overseas engineering contracting projects. On the other hand, based on the fact that the logistics costs account for $10 \%$ of the total contract amount, which is a conservative estimate, China's annual turnover in 2013 of international engineering project logistics management is more than $\$ 13$ billion.

So, analyze the logistics management at the present stage of China's overseas engineering contracting projects, find the reasons for the problems combining with practice to find out the factors influencing logistics management, and in view of the main problems, conduct depth profiling, using it as a breakthrough to put forward optimization strategy to solve the problem, which has profound significance.

Related researches are mainly concentrated on the following aspects:

Researches based on the idea of project management and the life cycle theory [4]. Liyan analyzed logistics operation mode of international project from the perspective of life cycle. According to the characteristics and needs of different stages of international engineering project's life cycle, complete the design of logistics services for the project approval period, and give management method for the operation period and the end operation period.

Researches on the logistics operation process. Haiyun systematically analyzed the engineering logistics in EPC project. Comparing the advantages and disadvantages of thirdparty with that of fourth party logistics, he put forward the combination of third party logistics and the fourth party logistics, adjusting transport scheme, optimizing the supply chain and management, so as to reduce the transportation cost and increase the benefit of enterprises [2].

Specific case studies focused on the logistics modes of international engineering projects. Siyu, taking AP company as the research background and combined with knowledge of international project logistics, conducted in-depth analysis of the problems which exist in the current international project logistics of AP company. From the aspects of time, cost, quality control, give the optimization strategy[3].

The researches focused on logistics risk of international engineering projects. Jianping [1] decomposed the complex engineering logistics risk, and built a risk evaluation index system based on the decomposed factors. After weighting each risk index, the analytic hierarchy process is adopted, making it more reasonable and realistic. And further combing the fuzzy evaluation method and risk factor analysis, the risk evaluation model of engineering logistics is established based on the method of fuzzy comprehensive evaluation.

\section{Features of International EngineERING Projects LOGISTICS}

International project logistics is a form of logistics, taking the engineering project as the service object, and providing international logistics services. It is closely related to the relevant international projects, and its development is affected by the development of project management and logistics management. In recent years, due to the rapid development of international trade and the unceasing increase of international exchanges, international project logistics is the international economic trade activities of realizing economic globalization, whose importance has been recognized by the people.

In twenty-first Century, most of the country's economy has been in a relatively stable development period. At this stage, the development of international engineering project logistics has the following basic characteristics [3]:

- It is difficult to establish the international project logistics system. Due to the different levels of development of each country's technology and economy, the relevant policies and regulations are not the same, which makes logistics environment of each country or region are different, the implementation of logistics standard each are not identical, and brought difficulty to the establishment of the international project logistics system

- International project logistics involves a variety of modes of transport. International project logistics involve cross-border transport, ocean shipping, and with road transport, air transport, rail transport, which is a significant feature of the international project logistics. The global multimodal transport mode shortens the time of transit and improves the efficiency of the whole logistics system.

- International project logistics has a big span, which is reflected by two aspects, namely geography and time. The kind of projects materials is large, and the suppliers are from all over the world. On the other hand, some special materials have characteristics of customization, which need longer time. In addition, the transportation process is full of difficulties, which also cause longer time.

- International project logistics is supported by the international information system. International information system is an important means of international engineering project logistics. Through the international communication and sharing of information, the international project logistics can be smoothly carried out. The development of the international information system has a direct impact on the development level of international project logistics.

- International project logistics management has a characteristic of diversification. International project industry involves a wide range of fields, many types, which requires different project management methods, to promote the diversification of international project logistics management.

- Specialization degree of international project logistics is high [5]. International engineering project logistics management is more complex and professional than common logistics management, and it needs to have the relevant professional knowledge and work experience. This has led to the development of PMBOK (project management knowledge system), and led to the emergence of professional project advisory body.

\section{INTERNATIONAL ENGINEERING PROJECTS LOGISTICS MODES}

In projects logistics management, logistics service providers are the main forms as follows:

(a) Engineering contracting company alone investment to set up a logistics company.

(b) Engineering contracting company and its subsidiaries jointly establish a logistics company.

(c) Project contracting companies and other venture company jointly set up a logistics company. 
(d) Engineering contracting companies and other multitransportation and warehousing company build a long-term cooperation relationship.

(e) Engineering contracting company and a logistics company establish a long-term cooperative relationship.

The third party logistics (3PL) is a form that the contractor or the employer make the third party logistics enterprises assume of logistics enterprise logistics activities by contract agreement, which is widely used in large international projects. 3PL integrate all professional resources like other logistics companies, inspection agency, storage facilities, insurance agents, customs and customs clearance company, shipping company or railway company and so on, thus providing better service. After 30 years of exploration and practice, China's engineering contracting enterprises have a very in-depth understanding and research for large international project logistics management mode, risk factors, and risk control means, especially for the management of the third party logistics. But for those big project with tens of billions dollars investment, it often cannot achieve good results only relying on the traditional third-party logistics. In actual operation, projects logistics is lack of overall planning. The connection and communication between the third party logistics companies and engineering contractors, information transmission and fast response has increasingly become a bottleneck restricting the efficiency of logistics.

In recent years, the fourth party logistics (4PL), which is oriented to the whole supply chain management, has been widely used in the field of logistics. 4PL shows a series of advantages. The fourth party logistics is a supply chain integrator that organizes and manages the resources, capabilities and technologies of its own and complementary service providers, providing an integrated supply chain solution. In the aspect of engineering logistics, the fourth party logistics can make up for the deficiency of traditional third party logistics. But it needs a high-level management and organization.

\section{Problems Existing In Projects Logistics of INTERNATIONAL ENGINEERING CONTRACTING ENTERPRISES}

\section{A. Lack of real understanding of modern logistics concept}

Influenced by the traditional concept and the real environment, most of China's overseas projects contracting enterprises have not regarded logistics as an important aspect of enterprise management strategy, not taking serious study on it. Logistics in the enterprise are still operated simply and passively service the project with mechanical repeated pipeline like homework. At this stage, most of the management layer and the division of the international engineering contracting enterprises are mainly to open up the market, conduct auction sales, and increase the channels of cooperation etc. Maintain and strengthen the control of supplier delivery time and quality of the equipment. But for the intermediate links, namely the considerations and optimization of international logistics and transportation, they did no give enough attention.

B. The setting standard of logistics organizations is different and the centralized advantage and the decentralized advantage cannot coexist

Some enterprises are focused on the centralized mode of logistics management, setting up a logistics center or department in the internal enterprise. Through the warehouse sharing, centralized dispatch, optimal path, reasonable distribution, the centralized management can help save substantial operating cost for enterprises and improve efficiency. Information integration is also good. But this model is not conducive to make a quick response to the individual customer service demands. Some enterprise's logistics management will be distributed to each department, which does things in their own way with the product line as the watershed. This model is with more abundant product categories and trade and logistics mode diversification, but unable generating economies scale, and cannot reduce the logistics cost effectively [1].

\section{The lack of professional international logistics management and operational personnel}

International logistics of overseas project contracting companies is a comprehensive discipline including project management, mechanical and electrical, international trade, modern logistics, procurement, packaging, warehousing, international finance, and international accounting. Because of the extensive fields requirements, positions set should not only start from the perspective of cargo transportation, also take the feature of particularity of overseas projects into consideration. Personnel engaged in overseas engineering contracting projects of international logistics management and operation should not only master the professional knowledge of international trade and international freight, but also understand construction process of international project. The understanding of supply chain system, international financial business, and tax refund is necessary. But at present these professional personnel is very scarce.

\section{The need for the international logistics management information system did not draw enough attention}

In the process of economic globalization, the application and development of Internet and electronic information is one of the key factors to ensure the sustainable development of this process. Introducing high-tech means to logistics information can make the logistics speed up, improve the accuracy rate, reduce inventory, and reduce costs, which can extend and expand the traditional logistics function. But now it seems that configuration of international logistics management of contracting enterprises information system of China's international engineering is far from reaching its proper level.

\section{E. There exist contradiction between extensive mode of logistics and the intention of reducing cost and improving the efficiency.}

Most of the enterprises still extended the extensive mode of operation. There is no system planning and design of logistics management. They did not seriously learn from the experiences and lessons of the items shipped in the past, and have not summarized a set of overseas enterprise economic logistics development model suitable for the engineering characteristics. In the implementation of overseas projects of domestic enterprises, it seems that they have a directional thinking, that is they are taking the need of the project site as the focus of the work and the starting point, not in advance according to the specific environment at home and abroad, on the basis of summarizing the experience accumulated in other projects in previous shipment, combined with the construction steps of the overseas project and order. The fact is that what the scene need, what will be delivered from the domestic, which is no planning, so that in the later period of construction, in order to catch up with the progress, even regardless of the cost of large quantities of goods shipped, shipping costs will rise, coupled with the increasing frequency of use of cargo, logistics costs far exceeded the budget, which is unable to get effective control. 


\section{CONCLUSION}

By reading extensive literature, we found that the researches are mainly on the following directions. (1) Researches based on the idea of project management and the life cycle theory. (2) Researches on the logistics operation process. (3) Specific case studies focused on the logistics modes of international engineering projects. (4) Researches focused on logistics risk of international engineering projects.

It can be seen that almost no scholars study international projects logistics from the point of different market, namely different projects cite and standing in the stance of international engineering contracting enterprises of China. For example, for those international engineering projects in African, the condition is quite tough with scanty equipment supply, poor transportation, and even unrest social environment, which are seriously exerting negative impact on the projects logistics. From this point of view, we put forward the concept of "logistics sensibility". The factors effecting the logistics sensibility include materials supply ability, professional personnel ability, information and technology level, transport condition, social environment, government policy, economy development level, etc. So the logistics sensibility of African projects is higher than that of Southeast Asia.

The future analysis plan to stand at the stance of Chinese international engineering contracting enterprises, and analyze three levels of logistics sensitivity, namely different regional markets are divided into high sensibility projects logistics (in Africa), middle sensibility projects logistics (in South Asia), low sensibility projects logistics (in Southeast Asia and neighboring countries). Then, find the problems, and put forward suggestions on how to optimize it for international engineering contracting enterprises to improve their logistics management and obtain better profits.

\section{ACKNOWLEDGMENTS}

I want to thank my teacher $\mathrm{Yu}$ Yong. His profound knowledge and rigorous academic attitude deeply affect me, so that I benefit a lot in school. In the process of writing this paper, teacher $\mathrm{Yu}$ has put forward many valuable comments, and paid a lot of time and effort. Here I want to send my sincere thanks to the teacher $\mathrm{Yu}$ Yong!

During the writing of the paper, I communicate with the students. Encouraging each other and making mutual exchange of needed products help me avoid many misunderstanding. I want to thank them for accompany all the way, and I will remember this unforgettable time.

In addition, I want to thank my parents. Their understanding and support give me spare time and energy to finish my studies.

\section{REFERENCES}

[1] J.P. Hu, "Optimization Study on the Logistics Management of Z company's Overseas Engineering Projects," Capital University of Economics and Business, 2014

[2] H.Y. Yang, "Logistics Management of EPC Engineering Projects," The World of Building Materials,vol. 32, 2011, pp. 129-133.

[3] S.Y. Yan, "Research on Improvement Strategy of International Project Logistics for AP Company,” Tianjin University, 2013.

[4] L.Y. Yao, "The Logistics Management Approach Study of International Engineering Project based on the Whole Life Cycle," Tianjin University, 2014.

[5] K.T. Yeo, and J.H. Ning, "Integrating supply chain and critical chain concepts in engineer-procure-construct (EPC) projects," International Journal of Project Management, 2002. 